\title{
The Development of Wine Tourism in Atypical Wine Regions: the Challenge of Multistakeholder Cooperation?
}

\author{
Katleen Vos \\ Hogeschool \\ Dept. Media \& Tourism \\ e-mail: Katleen.Vos@PXL.BE
}

\section{Abstract}

In the last decades, worldwide wine tourism has been steadily progressing and has grown substantially as a research object. Several academic papers treat strategies for development and management of wine tourism. This paper aims to describe recent trends in wine tourism, and more specifically, the development of wine tourism in atypical wine regions. Therefore, it synthesises the key findings from the second UNWTO wine tourism conference.

Furthermore, it argues that the successful development of wine tourism is not an exact science. Emerging wine destinations often have many difficulties to overcome. Using literature review and case studies, it explores the possibilities to create successful destinations and highlights the importance of co-operation, co-creation within networks and creativity to create value for wine tourism destinations.

Keywords: wine tourism, atypical wine regions, UNWTO wine tourism conference 


\section{Wine tourism as a multi-stakeholder industry}

Wine tourism can be considered as a form of niche tourism that attracts a specific type of tourist that expects particular types of activities, focused on unique experiences, elaborated by a number of stakeholders that are interlinked with each other. According to Hall et al., wine tourism can be defined as "visitation to vineyards, wineries, wine festivals and wine shows for which grape wine tasting and/or experiencing the attributes of a grape wine are the prime motivating factors for visitors" (197). Very often wine tourism is a symbiotic relationship between two different industries; on the one hand, the wine industry based on agriculture and manufacturing, and on the other tourism, a service industry. Several studies have explored the cooperation between both industries.

According to Hall et al., there is an integration taking place both horizontally (within each industry) and vertically (between the industries). An example of this type of integration is the case of the Niagara wine tourism cluster, whereby Telfer notices interactions between both industries, but also with other organisations (e.g. accommodation), other clusters (agriculture and food cluster), governmental institutions and research bodies. Getz suggests that wine tourism can be perceived from three different perspectives: that of producers, that of destinations or "the territory" and that of tourists. The producers are concerned about educating their clients and selling their wine, the destinations see wine tourism industry as a strategy for the creation of visitor attractions, while the visitors are interested in visiting wine destinations.

\section{The supplier side}

Envisaging wine tourism from the supplier side, one can notice that wine producers in atypical wine tourism regions are often SME's and family businesses with a rather little capacity of job creation compared to producers in larger, well-established wine regions. Therefore, cooperation at the supplier side of wine tourism is of utmost importance for emerging atypical wine tourism destinations. As stated by Getz, strong, favourable, and unique destination associations are crucial for the development of wine tourism, particularly in rural areas.

There is a multitude of motivations to develop wine tourism. According to Dubrule, the two most important motivations are, on one hand, to increase the direct sales volume of the wine and on the other to increase the number of visitors in the wine regions. Dubrule also mentions that the wine tourism business is perceived to be a steady growing economic sector in Europe: there is a demand in society for quality products, for "terroirs," for the "typical" landscapes that are connected with a certain way of quality living, where one can practice leisure activities and participate in cultural events that are linked to these places. 
In some parts of the world, wine tourism is a strongly established economy, e.g. in well-known wine regions of France such as Bordeaux, Burgundy and the Champagne region. In other regions wine tourism is still in an embryonic stage as is the case in Belgium, for example. This illustrates that the level of development in wine tourism varies. So, there is a distinction to be made between highly developed and less developed wine regions or countries (Hall).

\section{The territory}

The concept of "terroir," derived from the word terre (land) is used in the wine industry to depict the unique characteristics of a place that influence and determine the wine that is made from the grapes grown in that place (McCarthy). Especially in France, the concept is used by winemakers to identify the particularities of wines from different vineyards. Nowadays, tourists search for "authentic experiences" linked to the terroir. Some scholars (Marlowe and Baumann) even refer to "terroir tourism."

Getz and Brown state that wine tourism can be regarded as a marketing opportunity for wine producers to educate and to sell their products directly to the consumers; for destinations it can be seen as a way to elaborate and market wine-related attractions and imagery, while for tourists it can be seen as a form of consumer behaviour. In many regions, wine tourism is considered as a tool for sustainable development, in particular, the rural areas, in which it is situated and which have previously relied on agriculture, extraction and manufacturing sectors. It has a significant role as a job creator. Moreover, the addition of value for the wine sector and the tourism sector plays a major role for destinations that are highly valued both by tourists and by quality wineries (Peris-Ortiz et al.).

According to Valduga and Valduga, tourism can significantly change a wine region as is the case in Vale dos Vinhedos in Brazil, where since the increase in tourism arrivals from the mid-199os on, the wine tourism offer has expanded, the rural activities diversified, and the landscape dramatically changed. The region was able to consolidate as a tourist destination, and the wines became more important in the national market.

\section{The wine tourist}

On the demand side, the wine tourist is the most important stakeholder in the wine tourism system. UNWTO perceives tourism as a demand-driven sector. Therefore, the motivational factors that lead to a wine trip should be taken into account and be incorporated into the tourism product. 
During the wine $2^{\text {nd }}$ UNWTO Global Conference on Wine Tourism, ${ }^{1}$ three wine tourist profiles were explored: the wine expert, the wine lover and the occasional wine tourist. The first has a broad knowledge of wines and visits the winery to buy, to taste and to learn about wine. The second type likes wine, has some experience in tastings and is eager to know more about the wine, whereas the third has a moderate interest in wine and wants to explore the region for non-wine reasons. The wine lovers and the occasional wine tourists represent the largest part of the wine tourism segment.

Experts participating in the conference agreed that for consumers each wine has unique features that differentiate it from other wines from other regions. This point of view offers new opportunities for the creation of new wine tourism destinations, as it suggests that wines that are perceived to be of high quality can be produced everywhere.

\section{The creation of wine tourism experiences}

The wine tourists are not different from other tourists in that they search for unique, authentic experiences. According to the experience economy model by Pine and Gilmore, the key factors to create these experiences are the 4 E's (education, aesthetics, entertainment and escapism). These key factors are applied by QuadriFelittito to explain wine tourism as an experience. Following wine tourism activities are listed as examples by Quadri-Felitti:

\begin{tabular}{|l|l|}
\hline \multicolumn{1}{|c|}{ Key factors of experience } & \multicolumn{1}{c|}{ Activities } \\
\hline Education & - Wine tastings and seminars \\
& - Culinary-wine pairing events \\
& - Home wine-making seminars \\
& - Cooking and craft-making classes \\
\hline Esthetics & - Consuming the 'wine-scape' \\
& - Enjoy unique lodgings and wines \\
& - Driving along scenic routes (along vineyards) \\
& - Art and craft fairs at the vineyards \\
\hline Entertainment & - Cellar concerts, music in the vineyard \\
& - Wine blending demonstration \\
& - Farm and food demonstration \\
\hline Escapist & - Vineyards hikes, cycling tours \\
& - Hot air ballooning over vineyards \\
& - Vineyard tours by horse and carriage \\
\hline
\end{tabular}

1 The 2nd UNWTO Global Conference on Wine Tourism was held on 29-30 September, 2017 in Mendoza, Argentina. 
Pine and Gilmore also suggest that an experience should be successfully themed before it can be staged. The theming involves scripting a story that relies upon the participation of the guests. In order to be successful, the creation of a theme should enhance a sense of place for the visitors.

Cooperation is a critical factor for success in the wine tourism sector when it comes to organising such experiences. The cooperation can be arranged at the intra-sectoral or inter-sectoral level. In the former case, there is cooperation within the wine sector or within the tourism sector e.g. wineries promoting their wines together or accommodation suppliers that sell their units through a common booking platform. In the latter case, there is cooperation between different sectors: the wine sector and the tourism sector, e.g. wine products are sold at tourism information centres, wine routes are elaborated along local bars and restaurants offering regional wines.

If a region or a terroir desires to expand its wine tourism activities, as stated by Croce and Perri, it is of utmost importance that it first identifies all its winerelated attractions. Furthermore, it should link these attractions according to a certain theme. Even if this is a rather complex exercise, once such a theme is defined, the terroir can foster its own identity and hence distinguish itself from other destinations, and thus acquire a stronger sense of place. Croce and Perri also argue that it is crucial for public and private stakeholders to cooperate in this process in order to be successful. Only then the region can bring together and organise all elements that define the region.

Guedes and Joukes describe the wine tourism in the Douro region as a catalyst for the region's economy as they research the relationship between the hotel boats and the wineries along the Douro river (Peris-Ortiz et al.). There, wine tourism is combined with river cruise tourism. The authors notice that the online promotion for the river cruises by the cruise companies is attracting an increasing number of international tourists to the wineries and the villages along the river.

The creation of wine routes is by many authors regarded as a favourable means by which many stakeholders on a regional level can be connected to co-create together regional wine experiences. They provide an excellent means to successfully connect a winery with the local community as well as with other wineries. A wine route can be defined as a tourist route that connects several wine estates and wineries in a given area, characterised by natural attractions, man-made attractions (wineries, wine estates, vineyards, and roads) and markers (signposts) to direct the tourist to the wine enterprises along the route (Vlachvei and Ourania). The combination of natural, cultural and social features that express the distinctive character of each wine route is usually noticeable. When moving between the wine routes, the tourist recognizes and values the difference in landscape and winescape (Hall). Sometimes tourists are also actively involved in the wine-making process; they might, for example, be invited by the wine producer to help them with the picking of the grapes 
and this can be seen as a form of co-creation. Both forms, cooperation and co-creation are key factors that are also applied in the UNWTO Prototype Methodology for the development of wine tourism destinations worldwide that was presented during the $2^{\text {nd }}$ UNWTO Global Conference on Wine Tourism (UNWTO).

\section{The UNWTO Prototype Methodology for the development of wine tourism}

The UNWTO Affiliate Members Programme ${ }^{2}$ has developed a Prototype Methodology as a "framework for wine tourism development through public and private sector cooperation. It can act as a plan as to how to create innovative tourism projects in such a way that they are beneficial to destinations, businesses and institutions. It requires compliance with the UNWTO Global Code of Ethics for Tourism and is aimed to maximise the socio-economic contribution of tourism while at the same time minimising its potential negative impacts" (UNWTO).

The UNWTO Prototype Methodology was first applied in 2015 in Spain as an initiative of the Leading Brands of Spain Forum. They proposed the development of a wine tourism prototype with five leading Spanish wineries. At the same time, the UNWTO Gastronomy network identified winery tourism as a great potential asset for destinations endowed with a wine-centred culture and heritage. In the first place, the wineries were seen as the lead stakeholders to produce experiences based on wine but also to offer a larger range of related experiences to suit any demand.

First, an assessment of the tourism potential of the wineries and their region was analysed. Then, a parallel analysis was conducted in other countries and also in potential generating markets for wine tourism in Spain. Furthermore, opinion leaders and scholars in wine tourism were involved in the process. Both branding and product development were investigated.

According to the scholars and the opinion leaders, the central theme of the place should be interpreted by the winery and reflected in the product. "The Joyful Journey" brand that was designed suggests a large range of experiences for the traveller that fit in the following themes: more time (experiences related to nature, history and culture), happier (gastronomy, local lifestyle, popular culture) and younger (activities that generate vitality: sports, well-being, care).

2 The World Tourism Organization (UNWTO), a specialized agency of the United Nations, advocates forms of tourism that contribute to economic growth, inclusive development and social, economic and environmental sustainability. UNWTO brings public and private initiatives together through its Affiliate Members Programme, which develops policies and instruments to encourage competitive and sustainable development through public-private partnerships. 
As a conclusion, it was stated that, if well-planned, wine tourism can become a powerful tool to enhance and preserve the cultural heritage of a region. To achieve this, it must connect the product to its surroundings by offering a complete experience to its visitors, beyond the visits to wineries and wine tasting: e.g. by visits to nearby museums, outdoor activities for non wine-drinking visitors, wine-related events. Furthermore, each winery is exploited as the tourism interpretation centre of its surroundings and can be imagined as a 'node' in a network of wineries, so travellers can tour from one winery to another. Applying Quadri-Felliti's model of the creation of experiences for terroir tourism to the UNWTO prototype methodology, it could be suggested that the UNWTO prototype follows similar reasoning for the development of valuable wine tourism experiences.

Nowadays, storytelling is a popular tool for the production of tourism experiences and is particularly relevant to wine tourism, as travellers want to feel immersed in the culture of winemaking to discover the people and the community behind the wine product. Wine destinations that answer this need by providing authentic, unique and emotional experiences will be the most successful according to experts of UNWTO (UNWTO). The stories told should be clearly articulated and consistent with the traveller's perceived image of the region and the country. Therefore, wine destinations should put people forward in their narrative. This offers an opportunity for emerging wineries and destinations to compete with those well-established ones (UNWTO). This way, the UNWTO prototype methodology offers a useful tool to identify the symbiotic relationship of the wineries and their settings, such as their impacts on local and regional history and culture as well as on the socio-economic situation (UNWTO). This tool can be adapted to and replicated in different regions, allowing for destinations to be promoted through their wine context by accentuating other aspects such as culture, history and tradition.

\section{Challenges}

Developers of wine tourism sometimes have to face specific challenges: they might encounter difficulties concerning the political requirements that are associated with opening a business in the region, whereby they sometimes lack financial support. This revealed that the benefits of developing wine tourism should be clearly communicated to governments at different levels. Not only financial support can be missing; in some cases, a poorly developed transportation network might discourage travellers from visiting the destination.

Dubrule also notices in his research that there might be some barriers that wine tourism areas are confronted with: 
- the wine business and the tourism business are rather unknown to each other

- in most of the cases, the quality of the hospitality as well as the tourism knowledge of the winemaker could be optimised

- the lack of commercial accommodation in the vineyards

- a problem of accessibility due to a lack of signalisation towards the vineyards, and

- a variable quality control system according to the sites.

Other types of challenges are linked to technical knowledge, natural resources and required investments for the production of wine. Furthermore, it is often quite a task to achieve coordinated public-private collaboration.

\section{Case studies}

In order to illustrate the methodologies and challenges mentioned above, two case studies are explored more thoroughly: the case of Belgian Limburg and the case Mendoza. Both cases are emerging wine tourism destinations in atypical wine regions. However, they are situated in different geographical contexts and are in different stages of wine tourism development.

The case of Belgian Limburg is presented first as an emerging atypical wine region. Secondly, the focus will be on Mendoza, Argentina that has already successfully applied the UNWTO Prototype Methodology for the development of wine tourism.

\section{Case study: the development of wine tourism in Belgian Limburg}

The province of Belgian Limburg is situated in the northeastern part of Belgium, close to the border with the Netherlands. This province has known a period of economic crises as it suffered from the closing of the coal mines in the late 1990 on and of some major international companies who moved their activities to other countries during the last decade. Furthermore, the region also saw a significant part of its fruit export to Russia being blocked by a trade embargo.

In this economic context, tourism was considered as a way of tackling the crises and getting the economy back on track. Tourism was defined as one of the main axes of the SALK project (a Strategic Action Plan for the Belgian province of Limburg). Nowadays, tourism is one of the main economic activities in this region with 34.781 persons employed in the leisure economy (Provincie Limburg). The same SALK project also provided a financial input for the development of wine tourism in the area as it is one of the most important wine regions in Belgium in quantity 
and in quality (Groot Zevert et al.). However, in size it is still quite moderate: in total Belgian vineyards count approximately 200 hectares which is the size of an average French domain (Groot Zevert et al.).

According to the statistics of the average tourism expenditure in the province of Limburg in 2017, the average tourism expenditure per person in Limburg in 2017 was €95 per night (Provincie Limburg). The subregions where the average impact per person per night is high are first the Limburgse Kempen (€1768 per person per night), a region with thriving holiday resorts offering also attracting business tourism, secondly Hasselt, the capital of the province ( $€ 145$ per person per night) and, in the third position, the subregion of Haspengouw ( $€ 1351$ per person per night), the second-largest fruit production region in Western Europe (Provincie Limburg). Most of the vineyards of Limburg are situated in this subregion (Groot Zevert et al.). Here, most accommodation is provided by bed-and-breakfasts that are often located in former farmhouses or castle farms, but also more innovative accommodation facilities, e.g. treetents, are offered.

A strong tourism product in the province of Belgian Limburg is the bike road node network, a bike road system, based on former wayfinding techniques in the coalmines. This numbered system of bike road nodes is one of the main tourist attractions in the province, as it attracts yearly about 2 million tourists. It has existed for nearly 25 years and has created a vast network of stakeholders that are connected to deliver a wide range of services linked to biking tourism: from accommodation with places to store bikes and local cafes that sell repair sets, to an application that outlines the routes according to the tourist's wishes.

Some parts of these routes are designed in a creative way to deliver memorable experiences for biking tourists. They are aimed to appeal to all senses, e.g. biking through water, biking in the trees, biking underground, which reflects also the aesthetical and the escapist aspects of the 4 E-model by Pine and Gilmore.

Compared to this form of tourism, wine tourism is still in an embryonic stage in the Belgian Province of Limburg, although wine has been cultivated in this area since the $11^{\text {th }}$ century. Due to climatic and other reasons, wine-producing had been abolished from the $16^{\text {th }}$ century on but has known a revival from the 1990 os on, when the first steps towards wine tourism were taken. Some wineries have already been active since the 1990 and have elaborated a range of tourism activities around their vineyard, but mostly their offer is limited to the traditional wine tastings and visits to the vineyards and caves.

To enhance the attractiveness of Belgian Limburg as a wine tourism region, it is thought that it is necessary to foster an own local wine identity and to connect the tourist attractions that are designed around the wine (Groot Zevert et al.). Nowadays, biking and Vespa tours are organised along the vineyards, connecting several tourism spots and artistic landmarks in the area. Breakfasts and lunches can take place in some vineyards. 
Another inspiring example of how this is done can be found in Mendoza, Argentina, where wine tourism is developed through the Prototype Methodology for Development of wine tourism constructed by $\mathrm{UNWTO}^{3}$ (UNWTO).

\section{Case Mendoza}

The Mendoza region is situated at the backdrop of the Argentinian Andes and known as the centre of Argentine winemaking, even though its natural conditions were not very favourable initially. Thanks to an ingenious system of water supply imported by early Spanish immigrants and methods of wine-producing introduced by Italian migrants in the $19^{\text {th }}$ century into this desert region, vines can thrive there. Nowadays, wine production accounts for $70 \%$ of the national wine production and about $85 \%$ of the bottled wine sales. Its identity is firmly connected to wine and it offers visitors the opportunity to visit a variety of wine tourism projects, linking both the public and private stakeholders of the tourism and wine sectors.

Wine tourism development in Mendoza has taken place using the methodology of the Prototype for Wine Tourism Development of the UNWTO (UNWTO). This methodology is focused on three main questions. First, the differentiation from similar products is explored, then an innovative approach is aimed at by connecting persons that are not used to working together and thirdly, it is oriented towards value creation. For the latter, as Kotler states, supply and meaning is the future of value proposition in marketing (Kotler).

As stated above, the concept was first launched and tested in Spain and later also implemented to other destinations. It is aimed at the creation of an unforgettable, memorable and happy journey: the tourism product is so innovative that tourists discover the wine region in an entirely new way and Mendoza can improve the competitiveness of the region.

One of the features of the methodology was also the design of a logo/brand with the promising name "Joyful Journey," which relates to the experiences offered to the tourists: "live longer, be happier and stay younger" (UNWTO). The "vineyarding in Mendoza-in the Clouds of Malbec" connects all components of the wine value chain, aiming at "building the ideal tourism" product. Wine experiences are based on the agricultural variety of products, of landscapes and the rich handicraft heritage of the area. All created products contribute to sustainable development

3 The Prototype Methodology provides a roadmap for such processes based on initial research and analysis. It can incorporate a governance model, a catalogue of tourism products to be developed, strategies for market positioning and messaging and a brand identity. The Prototype Methodology entails compliance with the UNWTO Global Code of Ethics for Tourism so as to maximise the socio-economic contribution of tourism while at the same time minimizing its potential negative impacts (UNWTO). 
in the region. The products that are designed are often a combination of several different types of experiences, e.g. tango and wine, movie and wine, sports (cycling, golf, marathon) in or through the vineyards or even spa tourism and wine (whereby products, derived from grapes are offered). Local governments build routes, linking wineries with hotels and restaurants, taking care of accessibility, signalisation and education of the personnel and facilitate information exchanges between the wine producers.

Although both destinations differ in terms of wine tourism development, some similarities can be encountered:

\begin{tabular}{|l|l|}
\hline \multicolumn{1}{|c|}{ Similarities } & \multicolumn{1}{|c|}{ Differences } \\
\hline $\begin{array}{l}\text { Both regions enjoy a } \\
\text { favourable climate for wine } \\
\text { tourism. }\end{array}$ & $\begin{array}{l}\text { The geographical context and the landscape are } \\
\text { rather different: at one hand a desert area close to } \\
\text { the Andes mountains in Mendoza and at the other } \\
\text { hand: a plateau region of low, rolling hills and rather } \\
\text { fertile soil in Haspengouw in Belgian Limburg. }\end{array}$ \\
\hline $\begin{array}{l}\text { Both regions developed wine } \\
\text { tourism in an atypical wine } \\
\text { region. }\end{array}$ & $\begin{array}{l}\text { Stage of wine tourism development: both } \\
\text { destinations seem to be in the development phase } \\
\text { according to the Tourism Area Life Cycle of Butler } \\
\text { (Butler). However, Belgian Limburg is still at the } \\
\text { beginning of this development phase (close to the } \\
\text { involvement phase), whereas Mendoza is already } \\
\text { evolving towards the consolidation phase. }\end{array}$ \\
\hline $\begin{array}{l}\text { Both cases show that wine } \\
\text { tourism is a multi-stakeholder } \\
\text { business. }\end{array}$ & $\begin{array}{l}\text { Thanks to the implementation of the UNWTO Wine } \\
\text { tourism prototype, Mendoza has already built a quite } \\
\text { strong reputation as a wine tourism destination on } \\
\text { an international scale, whereas Belgian Limburg is } \\
\text { known as a wine tourism destination on a national } \\
\text { level and in the surrounding countries. }\end{array}$ \\
$\begin{array}{ll}\text { in Mendoza seems to be already well established } \\
\text { (estates, bodegas, restaurants, markets and tour } \\
\text { operators work together to offer an extended range } \\
\text { of wine tourism products, e.g. wine and wellness, } \\
\text { wine and movies at the vineyards), Belgian Limburg } \\
\text { still needs to expand its wine tourism network to } \\
\text { carry on the wine tourism development. }\end{array}$ \\
$\begin{array}{ll}\text { Furthermore, Mendoza offers already a wide range } \\
\text { of wine tourism products. Belgian Limburg has only } \\
\text { taken some small steps in this direction. }\end{array}$ \\
\hline
\end{tabular}




\section{Conclusion/Lessons learned}

The wine tourism sector represents a promising niche tourism market that offers a large set of opportunities to diversify the tourism offer. The main lessons learned for wine tourism developers are situated at multiple levels and are different for each stakeholder in the process of wine tourism. Designing a wine tourism product can represent quite a challenge. However, a strong connection to its environment through the integration of natural and cultural elements such as gastronomy or art, can be the key to success.

The combination of the above-mentioned elements with efficient management and a well-organized communication strategy will generate authentic and innovative experiences that will fascinate and inspire any traveller. For tourism managers, the main role is to bring together the different actors in a larger network of cooperation based on partnership and cooperation. This is intended to involve the local communities and to support the SME's in the region.

The cases shown above indicate that well-elaborated wine tourism can become a powerful tool to familiarize the traveller with the richness of the terroir, and then subsequently becoming a powerful catalyst for socio-economic development and the upgrading of the cultural heritage of a tourism destination.

\section{Works Cited}

Butler, R. W. „The Concept of a Tourist Area Cycle of Evolution: Implications for Management of Resources." Canadian Geographer 24.1 (1980): 5-12.

Croce, E., and G. Perri. Food and Wine Tourism. Wallingford: CABI, 2017.

Dubrule, P. L'oenotourisme: une valorisation des produits et du patrimoine vitivinicoles. Paris: Ministère de l'Agriculture et de Pêche, 2007.

Getz, D. Explore Wine Tourism: Management, Development and Destinations. New York: Cognizant, 2000.

Getz, D., and D. Brown. „Critical Success Factors for Wine Tourism Regions: A Demand Analysis." Tourism Management 27.1 (2006): 146-158.

Getz, D. et al. „Critical Success Factors for Wine Tourism.” International Journal of Wine Marketing 11.3 (1999): 20-43.

Groot Zevert, N., et al. De uitbouw van wijntoerisme in de provincie Limburg. Leuven: unedited, 2015.

Guedes, A., and V. Joukes. „Hotelships on the Douro River and their Relationship with the Terroir." Wine and Tourism. Eds. M. Peris-Ortiz et al. Cham: Springer, 2016, pp. 87-105.

Hall, C. M., et al., eds. Wine Tourism Around the World: Development, Management and Markets. Oxford: Butterworth-Heinemann, 2000. 
Kotler, P., et al. Marketing 3.0. Hoboken, NJ: John Wiley and Sons, 2010.

Marlowe, B., and M. J. Baumann. Terroir Tourism: Experiences in Organic Vineyards. 4 April 2019. http://dx.doi.org/10.3390/beverages5020030.

Marlowe, B., and S. Lee. „Conceptualizing terroir wine tourism.” Tour. Rev. Int. 22 (2018): 143-151.

McCarthy, E., and M. Ewing-Mulligan. Wine for Dummies. Hoboken, NJ.: John Wiley \& Sons, 2007.

Peris-Ortiz, M., et al., eds. Wine and Tourism A Strategic Segment for Sustainable Economic Development. Cham: Springer, 2016.

Pine, B. J., and J. H. Gilmore. The Experience Economy: Work Is Theatre \& Every Business a Stage. Brighton, MA: Harvard Business, 1999.

Provincie Limburg. „Limburg in cijfers.” Accessed 20 Feb 2019. https://limburg. incijfers.be/.

Quadri-Felitti, D. L. An Experience Economy Analysis of Tourism Development along the Chautauqua-Lake Erie Wine Trail. Ames, Iowa: IOWA State University, doctoral dissertation, 2012.

Telfer, D. J. „From a Wine Tourism Village to a Regional Wine Route: An Investigation of the Competitive Advantage of Embedded Clusters in Niagara, Canada." Tourism Recreation Research 26.2 (2001): 23-33.

UNWTO. UNWTO Wine Tourism Prototype. Madrid: UNWTO, 2017.

Valduga, V., and M. Valduga. „The Experience of Wine Tourism in Vale dos Vinhedos - Rio Grande do Sul- Brazil." Wine and Tourism. Eds. M. Peris-Ortiz et al. Cham: Springer, 2016.

Vlachvei, A., and N. Ourania. „Wine Routes in Greece: Producers' Perceptions and Economic Implications." International Journal of Arts and Sciences 3.2 (2009): 95-106.

Katleen Vos - lecturer in Tourism \& Recreation Management at the Hogeschool PXL in Hasselt, Belgium. She obtained her MA in Tourism at the University of Leuven (KULeuven) with a thesis on the role of cultural heritage in the revitalisation process of traditional thermal resorts. She worked as well as a junior researcher at the University of Leuven on the ESPON Project 1.3.3. The role and spatial effects of cultural heritage and identity. In 2007 she was a consultant for an international management consultancy, where she focused on the development of public policies and strategy from local to EU levels. She was also a contracting manager and part of the sales analysis team of TUI Belgium; a travel advisor specialised in cultural tours. Prior to that, she took a pgDip. in European Tourism Management at the Universities of Bournemouth and Chambéry (1992-1993). 
Katleen Vos

\section{Images}

1. The landscape of Mendoza

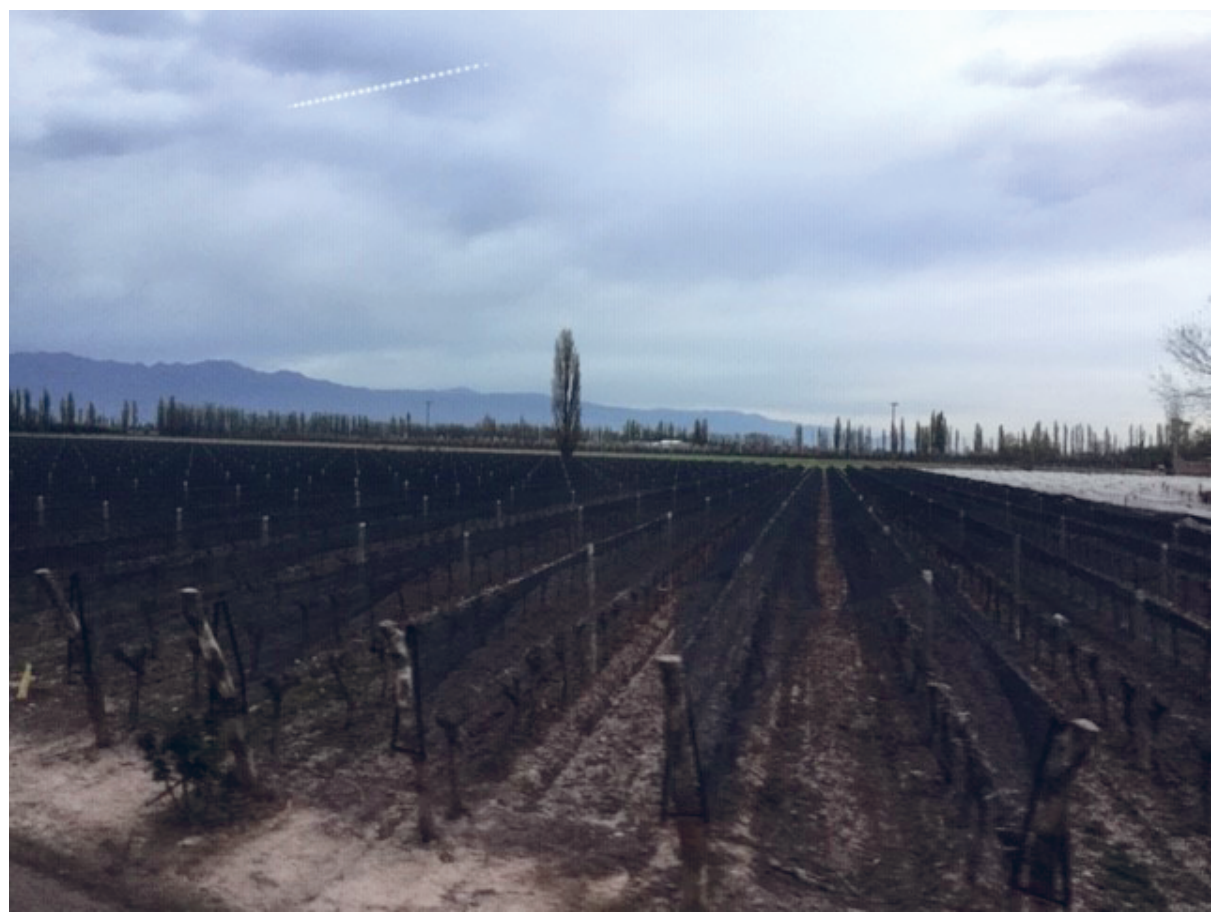

Source: Vos, K. 


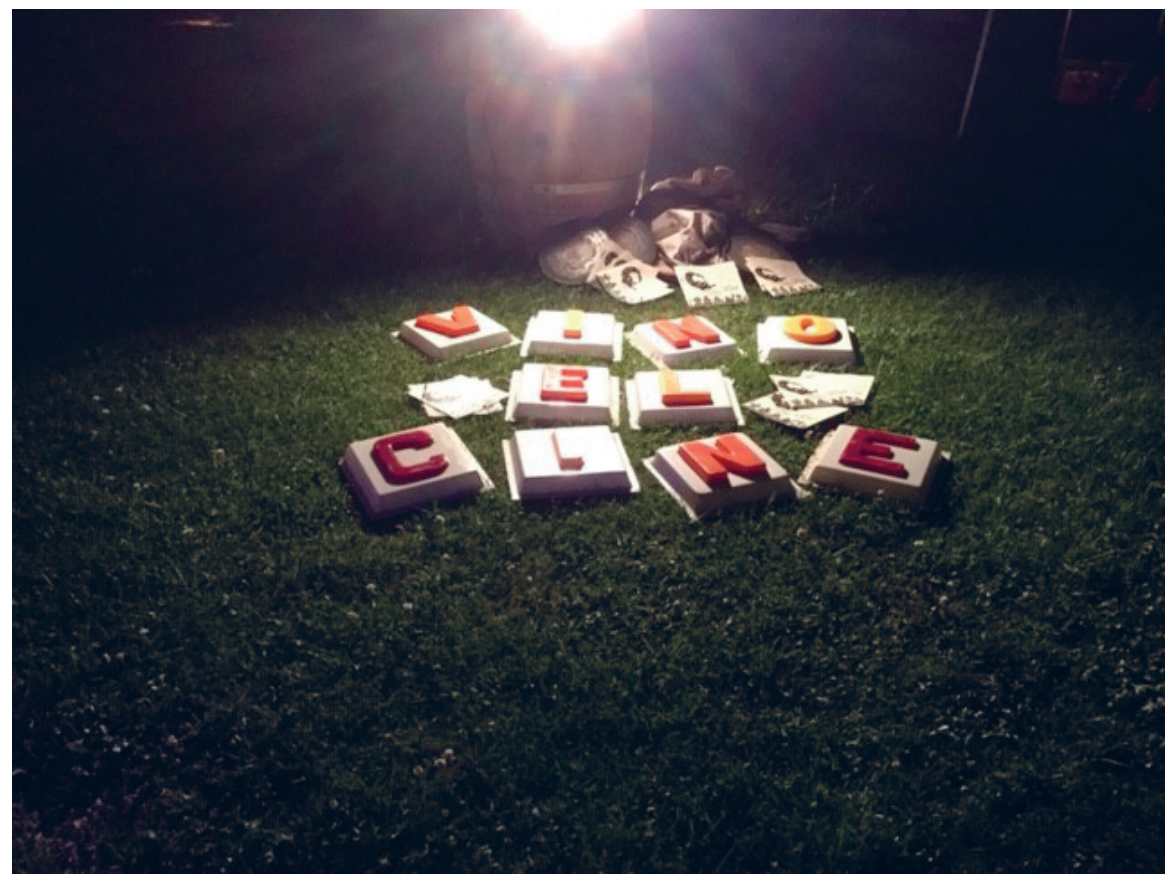

Source: Vos, K.

3. The wine-castle of Genoels-Elderen (Belgian Limburg) - AOC Haspengouw

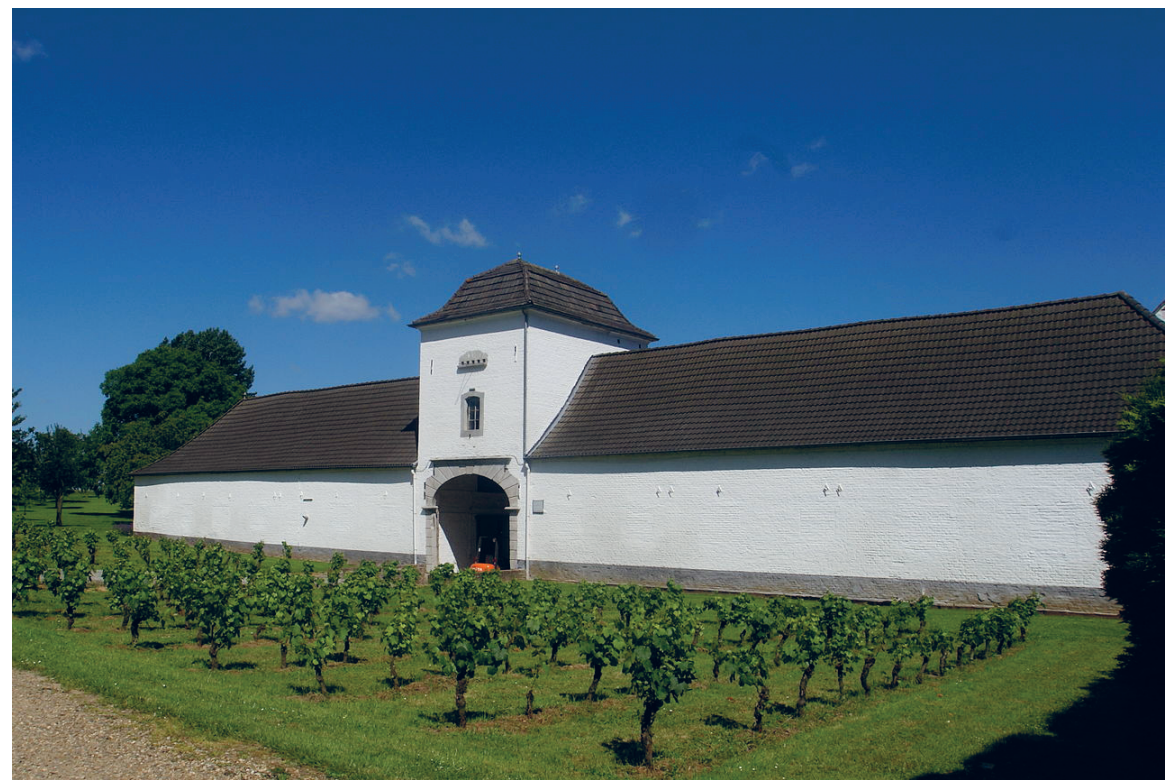

Source: https://creativecommons.org/licenses/by-sa/3.0/ 
Katleen Vos

1. Tree tents in Borgloon

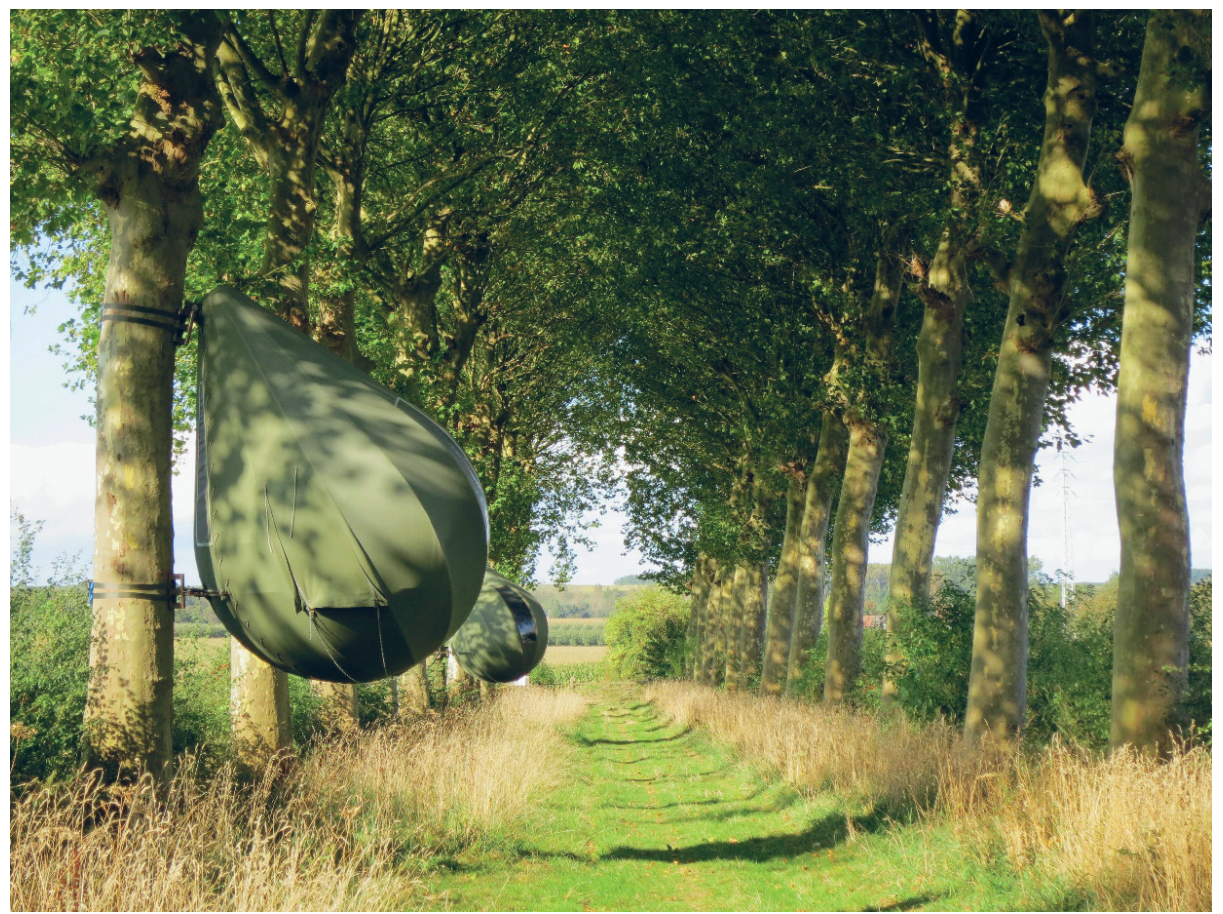

Source: Budenaerts, G. (https://www.panoramio.com/photo/79476420)

2. 'Reading between the lines' - artwork

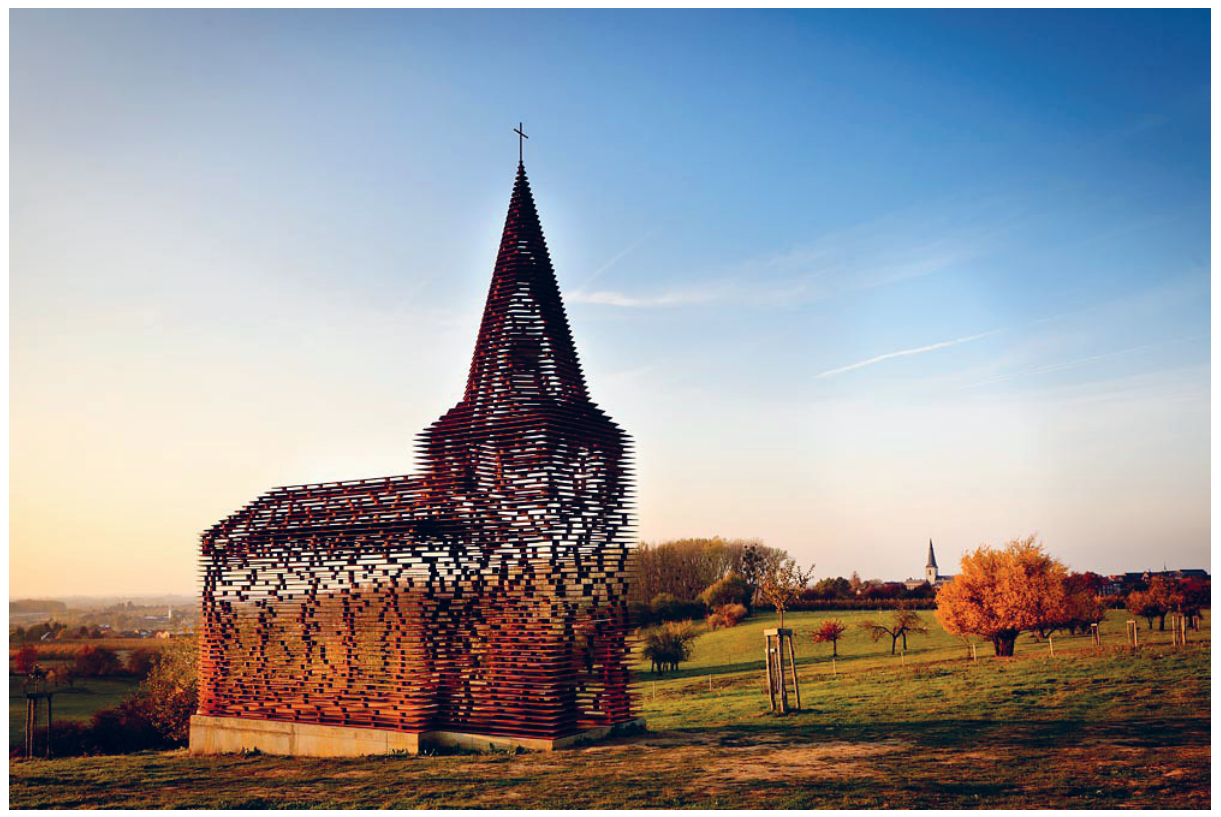

